\title{
Eugene O'Neill and the Celebration of The Other
}

\author{
Sayyed Rahim Moosavinia (Corresponding author) \\ Shahid Chamran University of Ahvaz \\ E-mail: moosavinia@yahoo.com \\ Yasaman Kocheili \\ Islamic Azad University - Karaj Branch
}

Received: 11-11- 2012

doi:10.7575/aiac.ijalel.v.2n.2p.59
Accepted: 25-12- 2012

Published: 01-03- 2013

URL: http://dx.doi.org/10.7575/aiac.ijalel.v.2n.2p.59

\begin{abstract}
The present paper examines Eugene O'Neill's three selected plays, Anna Christie, The Iceman Cometh and The Hairy Ape, in the light of cultural studies by focusing on finding the notion of the "other", here women, blacks and the working class. The chosen groups here are among the ones that have been "otherized" by the white, male, bourgeois society. In this study, through the elements of cultural studies, it is shown that the mentioned groups are treated as Others because of their gender, class or race which are considered as inferior ones by the Power. We are going to find out that thinking in terms of binary oppositions is not an acceptable point of view in cultural studies. Therefore, the boundary between the superiority of the Power and inferiority of the Other is broken in this approach. O'Neill's view point in the selected plays is in line with the core ideas in cultural studies. His wide point of view toward the events of his country and his pluralistic and skeptical outlook does not let any simple categorization or generalization takes place in his works. He criticizes the dominant discourses of the society and makes room for other voices to be heard.
\end{abstract}

Keywords: Hegemony, binary oppositions, ideology, identity, multiculturalism, the other

\section{Introduction}

Eugene O'Neill (1888-1953) is the father of serious American drama. Before him what was known as drama was mostly farce or melodrama. He brought depth to American drama by discussing serious social, cultural, political and economic issues of his society in his plays. In many of his plays especially the three selected ones for this article, The Iceman Cometh, Anna Christie and The Hairy Ape, the multicultural society of the United States and the socio-political events of the day are seen.

The Iceman Cometh was written in the year 1939-in the 30s- which was a very crucial decade in the history of America due to the fact that the failure of capitalism and the rise of Stalin happened then. It also was a post-war decade and the beginning of another war. In the play, there are references to these events and other important social, philosophical, economic and political issues of the day.

The play takes place in a bar downtown New York which is a place for a community of drunk people who once had important roles or jobs in the society but now seeking oblivion by keeping alcohol their company. Each character of the play is the representative of a group of the society, but now these people do not have any direct contact with the outside world and society. The only people who live in the outside society are three prostitutes and a salesperson, Theodor Hickman. From the different layers, themes and characters of the play, this paper focuses on the job and life of one of the characters, Joe Mott, who is the representative of the black society to elaborate on the relationship between race and culture.

The other play, Anna Christie, is a story of a woman who due to the bad economic conditions of her family becomes a prostitute but she expects her father and her lover to respect her even as a prostitute. She does not accept to marry her lover, Burke, unless he accepts her as a free thinking woman. In the play when Burke found out that Anna is a prostitute he wanted to let her go and Anna, in order to preserve her pride and identity, wanted to leave, but at last with the acceptance of her past and thoughts and identity by her lover, she accepted to stay and marry Burke. Here, the importance of the relationship between gender and culture is highlighted.

In the last selected play, The Hairy Ape, there are a group of firemen, the leader of them, Yank, who from the beginning of the play have discussions about their lives and the difference of it with the lives of Bourgeois. They are working and living until one day a girl on the same ship, Mildred Douglas wanted to go and see where the firemen work. When she saw Yank and other men who were filthy because of their job she could not stand to be there. From this moment on Yank's life changes. He starts looking for his shattered pride and identity by going to Fifth Avenue, which was a neighborhood of rich people, he went to I.W.W, a center he thought might support workers, but at last he could not find any place in the society. Desperate he went to a zoo and he died there. Therefore, here the interrelation of class and culture is discussed. 
Here some earlier ideas on the topic are considered as the literature review. Clive Bloom in the book The American drama (1995) talks about the history of American drama and American dramatists and their changes throughout the years. This book is useful here because through it we understand that the themes in O'Neill's plays, as a good example of a particular type of dramatists, are exactly related to American history, society, culture and ideology. In the book The Plays of Eugene O'Neill: A Critical Commentary (1964) David Rogers analyzes O'Neill's plays including the three selected ones. In this book we find out how his plays are rooted in the American historical, social, political, economic contexts. Eugene O'Neill's America, Desire under Democracy (2007) is an interesting and useful book which shows the engagement of O'Neill's plays, especially The Iceman Cometh, to the American history, politics, society, and so on. It is a very useful source for proving that cultural studies can be beautifully applied to O'Neill's plays. The article "Eugene O'Neill" (1967) is another important source for this study. Raleigh, the writer, in this article states that in all O'Neill's plays the past is more alive and at work than the present. This is a very important point through which we can see why cultural studies can be applied to O'Neill's plays because all the approaches involved in cultural studies tend to examine the backgrounds, the contexts and processes in which people are born and grow. Stephen Grecco in his article "High Hopes: Eugene O'Neill and Alcohol" (1974) talks about The Iceman Cometh and some of its characteristics like distortion of the time and the dreamlike atmosphere of the play. These are among some of the elements we have in Postmodernism and also in American culture and ideology in which the illusion is more real than reality.

\section{Discussion}

In a society like America which has a long history in being considered as the "Dream Land", there are high expectations of experiencing success, happiness and equality in reality for every human being. But, in the works of many writers including Eugene O'Neill, there is a negation of the promises of the "American Dream." Harold Bloom (2007) in the preface to The Iceman Cometh says "O'Neill is not a celebrator of the possibilities of American life." In the selected plays here a different world, which is in sharp contrast with the promises of the "American Dream," is shown; a society of people who struggle with hopelessness and failure. So what happened to these people? Why are they so desperate and miserable? What happened to the "Dream Land?" Reading the plays, these questions and so many others may come to reader's minds. From O'Neill's and cultural studies point of view, what is universal and known about the U.S as the "Promised Land" is not the absolute reality. It is just a part of the reality, the reality of the lives of people who are in power, economic, political or cultural. This "power" which is White, Male, High class group of the society imposed their ideologies on the "Other" group which are Blacks, Women and Working Classes by creating a picture of the society and life for them that is just an illusion or in O'Neill's words in The Iceman Cometh, "Pipe Dream." The "power" which created the "pipe dream" either otherizes them or accepts them just in their own terms. In other words, women are either prostitutes or angles, working classes are accepted till they are working machines for power and blacks are either treated as non-person or they are accepted with negation of their own cultures. Therefore, this article tries to find answers to these questions:

\section{Why women, blacks and working classes are otherized?}

2. Are the binary oppositions such as white/black polar binary oppositions?

The belief, in cultural studies, is that people are marginalized by the power because of their class, race gender and other factors. In this article these are the three important ones. There is a relationship between these issues and culture to the extent that they are used by the power to disaffect people's ideology and identity.

Each of the selected plays elaborates on one of these issues; The Iceman Cometh will be read through Post-colonialism to focus on the issue of race, The Hairy Ape will be read through Marxism (the issue of class) and Anna Christie will be discussed through Feminism and Gender studies (the issue of gender). These approaches all gather under the umbrella term cultural studies.

\subsection{The Hairy Ape: the Manifestation of Two Classes in Binary Opposition}

Marxism believes in a one-way relationship between economy and culture. Economy is a base and other things are affected by it. What Cultural Studies got from Marxism is that economy, culture and consciousness are related but what is different is the belief that culture can be and is dependent from economy. What is important here and thesis is that "class" is an issue that is raised in both of the approaches and it is believed that due to this issue people are divided to high and low class while the low class are driven to the margins. In Cultural Studies this boundary is broken. John Hartley (2003) in the book A Short History of Cultural Studies says:

Marx believes that Culture is a product of the interests of the "ruling class" of the time. Such ideas achieved their fullest and purest expression in the U.S. In there the capitalist "belief system" of individual freedom in the pursuit of private prosperity was most fully "socialized." And this was the origin of Anti-Americanism in radical writing, including cultural studies. America became shorthand for corporate monopolistic capitalism. Belief in such American "values" as freedom, democracy, progress, technology, science, modernity and prosperity came to seem like so much more "false consciousness"(p.95)

The play is written in the expressionistic style of the theater. In expressionism everything such as the name of the characters, the setting and so on can be telling. Therefore, if the setting is a ship where firemen work, it is symbolic and it is not chosen by chance. It is chosen to highlight the themes of the play which are focusing on the lives of Bourgeoisie. 
The major characters of the play are Yank, Paddy, Long, Mildred Douglas and her aunt. The first three ones are the representatives of the working class and the last two ones are representatives of bourgeoisie. The play's scenes can be divided into two halves. In the first four scenes, the major character of the play, Yank, is unaware of the class struggle in the society and the effects of "class" on people's lives. In the last four scenes he becomes aware of the gap between the classes by confronting with Mildred Douglas. In the first four scenes, Yank's belief is that he is a useful and important member of the society and he is feeling happy and successful. He is introduced in the first act of the play as follows" Yank seems broader, fiercer, more truculent, more powerful, more sure of himself than the rest."(p.2) But confrontation of Yank and Mildred is the turning point of the play also Yank's life. Mildred called Yank "filthy beast" and this was the beginning of the shattering of Yank's belief in himself as a successful and useful member of the society. Yank began a quest to find his identity but by and by he understood that he belongs nowhere and considered as nobody in the society. Therefore, it is shown that a worker like Yank is just a tool for the economic power and if he wants to be treated as an equal human being, he belongs nowhere and has no identity. The power, economic and cultural, accepts the working class in a frame they defined for them; that is they are "other", lower and they are accepted as this or otherwise they have no other identity. But, this is a hidden secret until they become conscious of that. Antonio Gramschi, the Italian Marxist, in a book talks about "cultural hegemony." He says "Workers remain oppressed not simply by the economic and political power capitalism but instead by its "hegemony," its influence over popular culture and public opinion"(Diggins, 2007: 44) Therefore, it is this "cultural hegemony" which influences individual's consciousness and identity.

In The Hairy Ape O'Neill shows that the American Dream is a pipe dream created by the capitalists to rule the working class. Contrasting the promises of democratic America and the "dream land" to the reality of people's lives, people who are driven to the margins of the society, he shows the hidden part of the reality in the working class's lives. Therefore, the working class are manipulated by the economic and cultural power, that they are important and successful but this is just a trick to use them for their goals. According to the book Eugene O'Neill's America: Desire under Democracy" we should not allow the society to shape the self. O'Neill protested against "idealism" of moral hypocrisy and self deceit that society imposes on the individual."(Diggins, 2007: 4)

Yank thinks that he belongs because of the "false consciousness" that capitalism imposed on him. The capitalists created a class system where workers are just subjects for the capitalist's exploitation. According to Clive Bloom (2007) in the book The American Drama, "O'Neill's naturalism was and is deeply constituted in American popular economic and existential beliefs."(p.20) Therefore, not only Yank's belief in himself as the core of the society shatters, but he also couldn't find any place to fit in. His fate in O'Neill's point of view is determined by the economic and cultural hegemony of his society.

\subsection{Joe of The Iceman Cometh: the African-American as the Other}

Eugene O'Neill lived at a time when Americans of African descent were known as "Negros" or "colored" people. He was living in a country where black people were considered "second-class" citizens. He was familiar with the profound effects of ethnic prejudice on marginalizing people. He created sixteen black characters in a total of six plays between 1913 and 1939. This shows his concern about the black society.

One of these black characters is Joe Mott in The Iceman Cometh. What O'Neill intends to discuss about Joe's life is how "race" can be a tool for the power for marginalizing people. The power draws a border between the white race and other ethnicities, here the black race, and consider themselves superior, better and more cultured and treat the black as second-class citizens. Thus, O'Neill wants to reveal the ideologies of the white race that are imposed on the black race, he makes the society conscious of the interrelations of race and culture and how they can affect each other. Therefore, here again there is a cultural hegemony of white Americans and Europeans over the black race.

In the play, Cecil Lewis (The Captain) is the representative of the former and Joe Mott is the representative of the latter. There is a dialogue, in the play, between the two characters which is noteworthy.

Lewis. Good God! Have I been drinking at the same table with a bloody Kaffir?

Joe. Kaffir? Who's he? (p.21)

After Wetjoen, one of the characters of the play, explains to Lewis that he is not Kaffir and he is white, Lewis continues as follows:

Lewis. My profound apologies, Joseph, old chum. Eyesight a trifle blurry, I'm afraid. Whitest colored man I ever know. Proud to call you my friend, no hard feelings, what?

Joe. No Captain, I know its mistake. But I don't stand for "nigger" from nobody. Never did. (p.21)

What is implied in these dialogues is that white Americans and Europeans (Lewis as the representative) either look at people like Joe (the black society) as inferior and call them "nigger" and Kaffir, consequently legalize treating them differently, not as equal human beings, or they are considered white and they are treated equally but their whole identity and culture is negated. Either way their whole identity and culture is negated. This treatment of the black society comes from an ideology which says Black is savage, childlike and lower and white is cultured, educated and better. As Neil Campbell and Alasdair Akeen (2000) mention in the book American Cultural Studies

Native-Americans and African-Americans as well as immigrants from Europe and elsewhere, were seen as a thread until they brought within the acceptable definitions of "Americanness" or exclude from it entirely. White-Americans in position of cultural power defined Native-Americans as radically inferior, savage and in 
need of radical readjustment to the "better" life of the dominant culture. Alongside the struggles of AfricanAmericans within the dominant white culture. During the 1960s, there was also resurgence in many ethnic literatures - Native - Americans in particular. (p.48)

Thus, in a situation that African-Americans should be in the framework defined by the power or they are excluded, they start to find their own voice and regain their identity and place in the American history that its dominant historical voice has been white. Joe Mott of the play is the representative of this group of people. He tries to preserve his pride and identity among others.

In the second act of the play when Joe says he does not want to drink with Hicky, one of the characters, one of the bartenders sides with Hicky and then Joe says

Dat's my business. I ain't buttin' in yours, is I? sure you think he's all right. He's a white man, ain't he? Listen to me white, you white boys! Don't you get it in your heads I's pretendin' to be what I ain't, dat I ain't proud to be what I is, get me? Or you and me's goin' to have trouble." (p.48)

There are other similar dialogues by Joe in the play. He persistently wants to preserve his identity and he wants to be accepted as he is. He struggles for having an equal place among others and not be treated as other, to have the right to talk and do what he wants and to be who he is. Other. But others think that they have the right to bully and underestimate him. Other characters of Hope's saloon think that Joe should be thankful because they consider him as white and he belongs to their group as a consequence. They pretend that they are doing him good but Joe is aware of their racist and exclusive points of view. Due to Campbell and Keen ".... the master/slave system was grounded in denials of black history, identity, humanity, community, knowledge and language." (p.73) As it is mentioned in the quotation, the whole system is built on the binary opposition of power/other, master/slave and on ignoring the other/slave. This struggle continues to the end of the play and of the last things Joe says is, "Scuse me, white boys. Scuse me for livin. I don't want to be where I's not wanted." (p.93)

Therefore, although Joe was conscious of racism and its effects on his life he, he could not find an equal place in the society but at least he questioned the system which divided white/black into superior/inferior races. The fact of questioning the ideology of the power through Joe is one crucial step O'Neill takes to break the boundary of superioty of power and inferiority of other.

\subsection{Anna Christie: the Other Struggles to be Heard}

Female characters in the works of many writers come in special terms and specific categories. They are usually presented in extremes. Either they are good mothers, wives and so on or they are prostitutes or evil-like figures.

The difference of O'Neill's female characters with many others who categorize women easily, is that women come in all types in his plays. The roles they have in his plays are so various that they escape generalizations. He writes about women at a time in American history when feminists are making demands for divorce, education and so on. These issues show that he is concerned about women and he has a more humane point of view about women than many others. He does not put women into the framework he desires.

Anna Christie is one of his most important plays in depicting the theme of women's equality. In this play, he gives prominence to the female character; something that many writers do not do. As Steven F. Bloom (2007) mentions "Anna Christie marks the transition from his early naturalistic period to his middle experimental period, with its bold depiction of a realist, strong female character at the center of a metaphysical drama."(p.175)

In both Cultural Studies and Feminism the belief is that "gender" and "sex" are two different issues. They focus on gender because it is something that is created and defined not something people born with. It is created and defined by men. Therefore, all the points of view about women, all the categorizations and special roles defined for them in marriage, society and so on stems from a male-dominated ideology of a patriarchal society. One of the radical French Feminists, Helen Cixous, in her essay, "Sortis," (1975) argues that

Thought has always worked by opposition, by dual, hierarchized oppositions. All these oppositions are couples. Logocentricism subjects thought - all of the concepts, the codes, the values - to a two-term system so there are activity/passivity, culture/nature, day/night, head/heart, father/mother, intelligible/sensitive and so is about men/women. Theory of culture, theory of society, the ensemble of symbolic systems - art, religion, family, language - everything elaborates the same systems. She concludes that in these binary oppositions, always one is superior but this superiority is cultural not natural and therefore can be seen or defined in some other way. (p.287)

Men define women as less rational and associate them with "nature." They also categorize them either as objects of sexual desire or maternal figures, but women tried to define themselves a cultural role away from male points of view.

In Anna Christie, O'Neill through Anna, a free thinking woman, tends to interrogate and break the binary opposition of power/other in this play men/ women. In the play from the moment Anna starts to talk, it becomes clear that what kind of woman she is. She talks to Marthy, one of the characters, and she says," I never stand being caged up nowheres." And when she is telling the story of her life to her she says," It was all men's fault - the whole business. It was men on the farm ordering and beating me - an giving me the wrong start. Then when I was a nurse, it was men again hanging around, bothering me, trying to see what they get. And now it's men all the time, Gawd, I hate 'em all." (p.13) 
As we see in these dialogues, Anna hates being caged up, so she likes freedom. Furthermore, she is not optimistic about men. She believes that they affected her life in a bad way. Therefore, from the beginning, we see the traces that show she wants to be free and live her life independently and one of the huge obstacles on her way are men. As the play goes on, we see more references to the feminists' demands that I have talked about before. For example, when Chris sees his daughter for the first time he says, "Ay bet all men see you fall in love with you, py yimmy!" Anna answers," Cut it, you talk same as they all do."(p.15)

In the dialogue of Chris, there are references to the "male gaze" - The sexual look of men toward women. Anna gets mad. Her anger equals the resistance of the feminists to the male gaze and the way women are seen and represented by them. More and more we see the traces of the struggle between "mastery" and "servitude". In the play Chris and Burke are arguing with each other because Chris does not want Anna to marry him because he is a sailor. Each wants Anna to do what he wants her to do.

Burke. (to Anna) Go get dressed, I'm saying.

Chris. You stay right here, Anna, you here.

Burke. She'll not! She'll not! She'll do what I say! You've had hold her enough. That's my turn!

Chris. You don't do one tang he says, Anna!

Burke. She will so!

Anna. Orders is good!... You can go to hell, both of you! You're just like all the rest of them. Gawd, you'd think I was a piece of furniture!... Nobody owns me, see? 'cepting myself. I'll do what I please and no man can tell me what to do! I ain't asking either of me talk for a change! (p.p 42-43)

These dialogues are very significant. Reading them we see men's belief in being superior to women. Because they think this way, they assume they have the right to treat women as their properties, to order, to force them to do what they want them to do and they do not even leave a place for them to say their opinions. So in their dialogues, we see the point of view of men towards women. Then when Anna talks, in her sayings, we find out that she sees herself independent and free and she does not allow them to decide for her and therefore, she rejects the traditional belief that men are superior, they are more rational and they know better what is right. Anna stands up against her father's and Burke's bulling attitude towards her and she cannot tolerate that they are ignoring her like this and they want to impose their will on her.

Consequently, in her sayings that "nobody owns me" and "I'm my own boss", she makes an assertion of feminism's belief in freedom and equality of women. Also, when she says, "I can make myself a living", it shows that when men are money-makers of the family, they can subordinate women easier. This is very important because feminists always say that women should work for themselves and should be independent financially as well.

Anna's most constant emotions are her hatred of being owned and her love for the sea with the freedom it represents. All her life, other people have represented only suffering and slavery for Anna. Ana seems only to love a man when she sees weakness first. Otherwise, the man in his strength is too much a thread for her independence. (Rogers, 1964:14)

Therefore, Anna moves towards being free as much as possible and because in her new situation she feels freer she likes to be there. Also as it is said in the quotation as well as in the play, she cannot tolerate men. In fact when she came to the bar, she hated men but she loved Burke because she saw him after a shipwreck and generally she thought that he is different from other men. So now either Burke should prove his difference or she leaves.

After all the discussions and struggles to preserve her own pride and identity, Anna tells the truth to her father and lover about her job. She tells them before she came here she was a prostitute. Knowing this, Burke gets mad at her and Anna says she leaves him and goes back to where she was, Burke argues, "You mean you'll be doing the same again?" Anna's answer is affirmative. Then again he says," You'll not." Anna could not accept him being mad at her. She says," You been doing the same thing all your life, picking up a new girl in every port. How're you better than I was?"(p.56)

This is a very notable and interesting issue which Anna points out. It shows that even at this level she wants equality and she wants not to be looked at as the other; men are doing it for fun but she is doing it for money but they are accepted like this and she is not. Here in these dialogues the inequality of men/women is highlighted by Anna.

After the discussions about Anna's job, Anna talks to Burke about her love of him and she says she never loved a man before and this is the first time for her. Anna expects Burke to believe her and consider her love valuable. With this expectance, Anna is probing deeper into finding the goodness and difference of Mat Burke.

At last, Burke accepts Anna. It is important for Burke that Anna really loves her and it is important for Anna that Burke forgets about her past. Therefore, Anna, with preserving her pride and independence, gets what she wants and she can find and love man who respects and understands her the way she thinks and the way she is. Anna is a representative of women who hate men because they think they are superior; they are the center of everything. Through her life and her dialogues, we think of the effects of male-defined gender roles deeply and with understanding the male ideology otherized because of the male cultural hegemony and we see the deconstruction of the traditional beliefs about women through Anna who is the voice of all women. 


\section{Conclusion}

Studying the three plays of Eugene O'Neill leads the writer to draw interesting conclusions. Some are represented here.

Firstly, the United States was a country which considered itself as the center of the universe. It had a long history in colonization and imperialism and invested its political, economic and cultural hegemony over its colonies and also its own people. The White, Male, Bourgeois-dominated ideologies ruled everywhere. There was one voice, one identity one unified culture and that was of that group. But, from the 1960s onwards, with the social movements of Blacks, Women and other minorities also literary movements like cultural studies, the whole view changed. When Women, Blacks and working classes became aware of their oppression by the Power, deconstruction of the Center began. America is the country O'Neill writes about. In his works he moves towards this deconstruction and it is very meaningful in America because it has a long history in being considered as the "promised land." Therefore, when a writer like O'Neill writes about men and women, blacks and whites, bourgeois and working classes, one being in the Center and the other in the Margin, but he focuses on the lives and cultures of the Marginalized not the Center, it shows that he is in line with those who challenge and call into question the dominant discourses of the society, the most importantly the American Dream of success and equality for everyone. Thus, he does not believe in one center and one absolute truth.

Secondly, O'Neill establishes a link between drama and history. According to him past is the only valuable thing to write about and history is not only what is told but also what is remembered by people. Through this belief he interrogates the authority and validity of what is told and this is where other narratives come into the center and there is no longer one narrative but multiple narratives with the same level of importance and validity. Thus, the very fact that he establishes a dialogue between drama and history, whether it is racial, political, social, philosophical, etc, is to reveal that nothing is absolute and there is a possibility of seeing things from the perspective that is not known and orthodox for the power and maybe the society itself.

Thirdly, in O'Neill's works the characters are mostly immigrants from Europe and elsewhere who speak with their special dialects and in this various mixture of his characters, we see the American society. Therefore, his pluralistic view is approved of because the scene he sets includes different classes, genders and ethnicities of the society.

Fourthly, when O'Neill writes about women, he shows the ideology of power/ men in opposition to other/ women. Against a background of history of male-dominated ideologies, he introduces a woman who negates all the metanarratives of patriarchal society. The very fact of having a female character who is not the way that power has defined cancels the authority of men. It should be noted that he does not want the authority of women either. He just shows that in the binary opposition of men/women, women do not have the chance to be seen and heard as equal human beings. They are always represented as the "second sex," according to Simon De Beauvoir. So the traditional, known truths that are created and defined by men are no longer valid because the only reason of their validity is that they are onedimensional and exclusive.

Fifthly, in identifying with the working classes, he shows that the American Dream of success and happiness is an "ideological myth" that is created by the power(here capitalists) to exploit the working class. He shows this exploitation by uncovering that these working classes do not have any ideology of their own. They also do not have an independent identity. By focusing on their lives he brings them to the center so that they could find their identities. Of course, they are not successful in finding their identities and in finding their equal place in the society. But the fact of focusing their lives and showing that they are mere tools for the power proves that O'Neill's view is not in line with those in power and in his plays he is not the voice of authority but the voice of the worker who does not belong to the capitalist society.

Sixthly, by referring to colonial history and an era in Africa and America by Europeans and Americans, he contrasts Power/Other which in The Iceman Cometh are White Europeans and Americans/ African-Americans and WhiteAfricans and he shows the major discourses of colonialists and the effect of them on the colonized ideology and culture. On the other hand, he shows the colonized struggling for being themselves and for having their own ideology and culture.

\section{References}

Bloom, H. (2007). Bloom's Modern Critical Views: Eugene O'Neill. New York: BLOOM'S LITERARY CRITICISM.

Bloom, S. F. (2007). Students Companion to Eugene O'Neill. London: Greenwood P.

Campbell, N \&Alasdair, K. (2000). American Cultural Studies. ( $3^{\text {rd }}$ ed). London: ROUTLEDGE.

Diggins, J.P. (2007). Eugene O'Neill's America: Desire under Democracy. Chicago: Chicago UP.

Hartley, J. (2003). A Short History of Cultural Studies. London: SAGE.

O'Neill, E. Anna Christie. (1921).

O'Neill, E. The Hairy Ape. (1922).

O'Neill, E. (1946).

Rogers, D. (1964). The Plays of Eugene O'Neill: A Critical Commentary. New York: MONARCH. 